\title{
When Digital Intelligence Taking Over: Mechanisms in Addressing SMEs Readiness on Industry 4.0 in Malaysia
}

\author{
Mira Qerul Barriah Muhamad, Syed Jamal Abdul Nasir Syed Mohamad and \\ Norzanah Mat Nor
}

To Link this Article: http://dx.doi.org/10.6007/IJARBSS/v11-i1/8335

DOI:10.6007/IJARBSS/v11-i1/8335

Received: 17 November 2020, Revised: 10 December 2020, Accepted: 11 January 2021

Published Online: 24 January 2021

In-Text Citation: (Muhamad et al., 2021)

To Cite this Article: Muhamad, M. Q. B., Mohamad, S. J. A. N. S., \& Nor, N. M. (2021). When Digital Intelligence Taking Over: Mechanisms in Addressing SMEs Readiness on Industry 4.0 in Malaysia. International Journal of Academic Research in Business and Social Sciences, 11(1), 543-551.

\section{Copyright: (c) 2021 The Author(s)}

Published by Human Resource Management Academic Research Society (www.hrmars.com)

This article is published under the Creative Commons Attribution (CC BY 4.0) license. Anyone may reproduce, distribute, translate and create derivative works of this article (for both commercial and non-commercial purposes), subject to full attribution to the original publication and authors. The full terms of this license may be seen

at: http://creativecommons.org/licences/by/4.0/legalcode

Vol. 11, No. 1, 2021, Pg. 543 - 551

Full Terms \& Conditions of access and use can be found at http://hrmars.com/index.php/pages/detail/publication-ethics 


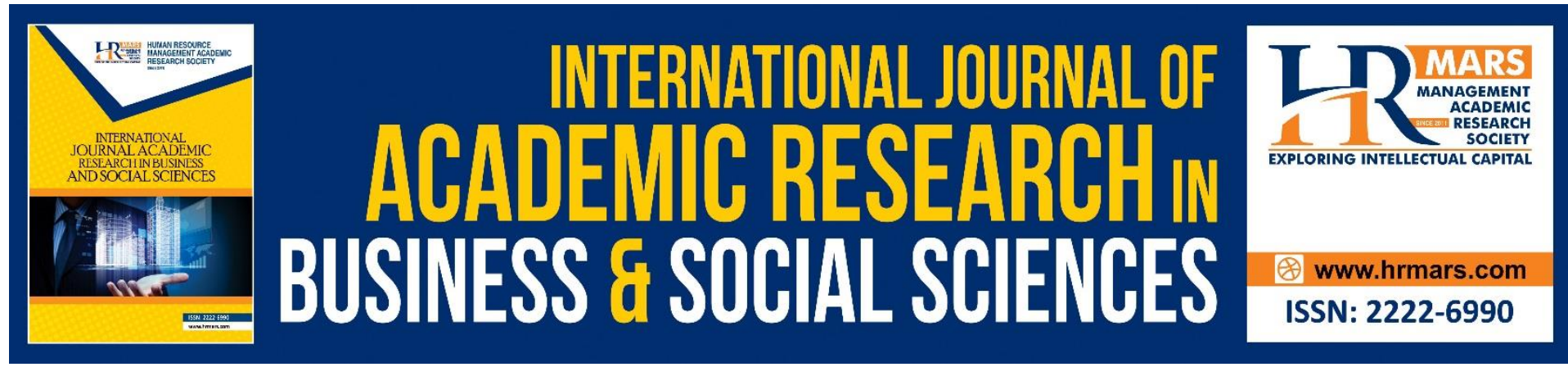

\title{
When Digital Intelligence Taking Over: Mechanisms in Addressing SMEs Readiness on Industry 4.0 in Malaysia
}

\author{
Mira Qerul Barriah Muhamad ${ }^{1}$, Syed Jamal Abdul Nasir Syed \\ Mohamad ${ }^{2}$ and Norzanah Mat $\mathrm{Nor}^{3}$ \\ ${ }^{1}$ Faculty of Business and Management, Universiti Teknologi Mara, 40450 Shah Alam, \\ Selangor, ${ }^{2}$ Arshad Ayub Graduate Business School (AAGBS), Universiti Teknologi Mara, \\ 40450 Shah Alam, Selangor, ${ }^{3}$ Arshad Ayub Graduate Business School (AAGBS), Universiti \\ Teknologi Mara, 40450 Shah Alam, Selangor. \\ Email:myraqerul@gmail.com, syedjamal145@uitm.edu.my,norzanah@uitm.edu.my
}

\begin{abstract}
For the past recent years, the fourth industrial revolution or famously known as Industry 4.0 has gained a large degree of intellectual interest. The usage of Internet augmented tremendously. Business models have been revolutionized and transformed accordingly, adding values to be commercialized. Industry 4.0 is a modern age of revolution in which businesses embrace innovative technology and digital transformation to improve productivity and competitive advantage to sustain in dynamic business landscape. Digital technology strengthens market environment by providing incomparable prospects for growth, employment and innovation. However, small and medium-sized enterprises (SMEs hereafter) in Malaysia faced several challenges in embracing the technology innovation offered by Industry 4.0. Growing evidence have shown that SMEs in Malaysia are not accustomed with enormous features of Industry 4.0 such as cloud computing, Artificial Intelligent, Internet of Things (IOT) and Big Data. Hence, this paper presents list of responsive mechanisms and coherent policies taken by Malaysian government and various authorities in addressing such challenges. Among the mechanisms and policies structured include provide funding and incentive, ecosystem support, training, coordinate standards and digital integration, build infrastructure and regulate the governance. This paper buttresses a notion that a proactive government is important for the march of better future.
\end{abstract}

Keywords: Industry 4.0, SMEs, Readiness, Digitalization, Malaysia.

\section{Introduction}

In modern-day mass society characterized by digitality, businesses from various industries have implemented Industry 4.0 as a mean to improve output productivity and efficiency of their business norms. With the advent of technology and new emerging ideas, they are deemed to adjust corporate strategies and evolve with the current trend to remain commercializeable. Industry 4.0 reflects a radical development of industry arising from the 
expansion of new innovations. Firms will be able to manufacture high-yielding quality goods with lower price and thereby improve competitive advantage with the possibilities pilot by Industry 4.0. Big data, Internet of Things (IOT) and smart factory are able to increase the performance of SMEs and have demonstrated to have a significant relationship with the production and services (Imran, Hameed \& Haque, 2018). Industry 4.0 typically refers to a set of transformation relating to the use new emerging technologies, leading to more adaptable, modernized and interconnected production processes (Molino, Cortese \& Ghislieri, 2020). In Industry 4.0, organizations are allowed to build innovative market model. Digitalization is speeding up worldwide, an indication that SMEs need to reinforce the execution of digital technology to sustain competitiveness. Most large corporations on the other hand have already mobilized Industry 4.0 and are actively reconstructing business strategies. The shifts in output and value generation as a consequence of the digital transition are radical. With some measures and mechanisms provided by the government, the challenges can be overcome.

According to Drath \& Horch (2014), the current industrial revolution was linked with other three revolutions in the past. They emphasized the first began with the introduction of mechanical production facilities, followed by the distribution of labour and discovery of electricity in Industrial Revolution 2.0 whereas the third was initiated as Information and Communication Technology (ICT) and modern electronics have catalyzed "the digital revolution", contributing massively to the progress and operations of production automation.

\section{Industry 4.0 in Malaysian SMEs}

The impact of entrepreneurship activities in Malaysia can be measured by various aspects. SMEs are made up of $98.7 \%$ of business entity and have been known as the main engine of economic growth in Malaysia. Recorded data indicates the contribution of SMEs to the total GDP rose to $38.9 \%$ in 2019 as opposed to $38.3 \%$ in 2018 , also an increase in overall exports in 2019 to $17.9 \%$ from $17.3 \%$ in 2018 and a growth in employment rate adding $48.4 \%$ in 2019 from 48.0\% in 2018 (Department of Statistics Malaysia, 2020). Figure 1 below has summarized the total contribution of SME GDP, gross exports and employment rate.

Figure 1: SME Performance in 2019

SME GDP

\section{RM552.3 bil [38.9\% share]}

(2018: RM522.1 bil) [38.3\% share]

SME

Exports

\section{RM176.3 bil [17.9\% share]}

(2018: RM171.8 bil)

[17.3\% share]
SME Employment

\section{3 mil workers} [48.4\% share] ${ }^{*}$

(2018: 7.1 mil workers) $\left[48.0 \%\right.$ share $^{*}$

* revised methodology

Source: (Department of Statistics Malaysia, 2020)

A local study has reported that Malaysian SMEs resonated for new innovations for the betterment of their business activities. A survey has been conducted on 2033 businesses and the result indicated half of them have invested in technologies to grow into new markets, attract new consumers and boost revenues (SME Corporation, 2018). Not only that, $50 \%$ of 
SMEs appeared to have intention venturing in ICT as a threshold of expanding business and develop competitiveness simultaneously, $30 \%$ are expected to be more effective and competent while the other $20 \%$ are still contemplating whether to invest or not (SME Corporation Malaysia, 2018).

In response to the changing domestic economy and emerging of business landscape worldwide, Malaysian government have amended economic policies over time. In 2009, Malaysia's Entrepreneur Growth Ministry (MED) has been abolished due to certain issues and re-established again in 2018. The restoration has the potential ensuring the betterment of SME programmes in Malaysia. A new National Entrepreneurship Framework (NEF) has been established by the new Ministry comprises of 21 objectives under four major policy headlines (MED, 2018). Developing innovative ecosystem, provide sources for grants and subsidy, setting up stakeholders' database and promoting established programmes are among the goals of NEF. However, albeit abundant categories of incentives introduced, Ling, Hamid \& Chuan (2020) admitted that policies introduced by the government of Malaysia will not likely be noticeable by people in general since it is regulated more towards technical experts.

\section{Problem Statement}

According to Ministry of Trade and Industry in their 2018 report, there is only $20 \%$ of digital adoption among SMEs and the use of automation by manufacturing firms are less than $50 \%$ which is very limited. Among other issues highlighted include shortage of essential expertise, abilities and knowledge for Industry 4.0, expensive cost of Industry 4.0 technologies and insufficient of centralized and ever-present portal to recognize best practises and implementations (Ministry of Trade and Industry, 2018). Muhamad, Mohamad \& Nor (2020) concluded in their study that Malaysia is confronted with a low degree of awareness on Industry 4.0 among SMEs, a lack of participation in innovation among small organizations, a scarcity of skilled workers and in short of resources and funding to embrace new technology. At its core, this is manifestly much to the disadvantage of SMEs.

Reports also indicated that Malaysian SMEs failed to be risk-taking, scarce of innovation and are not equipped for robust competition (Ismail \& Zakaria, 2018). The unreadiness of Industry 4.0 also exacerbated by insufficient trained labour force, little to no creativity by research and development (R\&D), a challenging market, less generously funding for infrastructure and unfavourable government policies (Musa \& Chinniah, 2016). Therefore, the low degree of participation and unpreparedness of SMEs in Malaysia for Industry 4.0 continues to be a worrisome matter and has prompted researchers to undertake this study so that SMEs can act on the mechanisms provided by the government to address their unreadiness.

\section{Mechanisms to Address Readiness Issues of SMEs towards Industry 4.0 \\ Funding \& Incentive}

To ensure continuous development of entrepreneurship among SMEs and amplifying economic growth, a continuous financial incentive provided by the government is prominent. In order to fund large-scale ventures, new financing blueprints and extension of established plans, involving collateral-free loans and connections to more efficient funding networks, need to be provided. Without the financial resources offered, it is almost impossible for small enterprises to incorporate their businesses into technology advancement due to its high-cost. In the second quarter of 2017, the acceptance rate for access to financing among SMEs is 
$97.0 \%$ and is reported lower to $89.8 \%$ in the third quarter 2017 and $18.5 \%$ from this accepted rate comprises of first-time borrowers (SME Annual Report 2017/2018).

However, the demand for loans from financial firms has lessened steadily as a consequence of the increasing cost of doing business and issues in rising cash flow. Central Bank of Malaysia, government agencies and other financial corporations are among bodies accountable for loan applications and more than $97.0 \%$ total lending offered by these institutions for SMEs (SME Annual Report 2017/2018). The government decision to lower the tax rate for SMEs with respect to reduce the cost of the business may alleviate their burden (Malaysian Investment Development Authority, 2018). This is one of few excellent stimulus to encourage more digital participation from various industries of SMEs.

\section{Ecosystem Support}

Supportive ecosystem is vital to promote Industry 4.0 innovation for incompetence SMEs solving problems due to inadequate resources and knowledge (Dallasega, Raunch \& Linder 2018). Infusing innovation culture as a mean to develop quality products and services can improve SMEs performance (Singh \& Hanafi, 2020). Innovative goods and services add consumer value thus increase competitive advantage. Such goods and services must however, be supported by a creative and diverse ecosystem. In order to keep up to date and meet potential demands of the economy, the existing ecosystem must be meticulously restructured and strengthened. The support provided from the corporate culture for emerging technology has indicated a positive relationship to the effective adoption of the technology (Zhu, Kraemer \& Xu, 2006).

\section{Training Providers}

Not only communication and information programs are effective in raising awareness, training on using new technology is also essential as it resonates to positive attitude and perspectives among employees on new technology (Molino et. al, 2020). It includes structuring and organizing constructive training and workshops, concentrating on key practises such as how to administer and manage digitized programmes (Agostini \& Filipini, 2019).

A number of projects has been introduced by Malaysian authority to enable SMEs to promote human capital and adopting innovation. Also, the projects include training on business skills and leadership development. Several policies established in support to encourage innovation development including programmes on enhancing human capital and reinforce entrepreneurship have led to compelling progression achieved by Malaysian SMEs (Organisation for Economic Co-operation and Development, 2018).

Another programme deliberated in spurring digitalization among SMEs is upgrading of expertise and guidelines for the successful use of technologies targeted to develop innovative goods and services for technology-oriented businesses. Other than that, National Dual Training System which involved a partnership between SME and University was announced with the objective to develop human capital targeted to school leavers and unemployed (SME Corporation Malaysia, 2018).

\section{Standards \& Digital Integration}

Most SMES nowadays exploiting the use of computers and Internet to digitalize their business. The exploitation improves connectivity and generate customer engagement effectively. It also modernizes their everyday operations. Some are using social media as a channel to develop new business potential and to build costumers relationship. Statistics has shown a surging of $6.0 \%$ from 2015 to 2017 in the contribution of e-commerce (Department of Statistics Malaysia, 2019). 
Government has come out with an initiative called e-Trade, an e-marketplace developed for SMES to commercialize products and making transaction in international business-to business (B2B) and business-to consumer (B2C) through MATRADE's website (Asian Productivity Organization, 2019). The Enabling e-Payment Services Program is another initiative focuses on making buying transaction easier by digital economy through expanding e-payment applications among SMEs.

Infrastructure

Infrastructure is one of the most substantial components in building a supportive environment for SMEs and entrepreneurs to grow. More than RM 600 million has been invested between 2011 and 2015 to construct company facilities, setting up incubators, develop industrial property and buy machinery for 7000 SMEs (Chin \& Lim, 2018). Other than machinery, infrastructure also include high-speed internet network, applicable system and software authorizing employees for virtual task and also smart devices such as smartphones, tablets and laptops.

The authorities in Malaysia have assisting SMES in innumerable ways as preparation for their business start-up. For instance, entrepreneurship development programmes that focused on funding infrastructure and equipment. Among agencies involved are Malaysian Palm Oil Board (MPOB), Malaysia Automotive Robotics and IoT Institute (MARII), Sirim Berhad, MARA and PUNB (National Entrepreneurship Policy (NEP) 2030, 2019). MPOB has organized a seminar and exhibition in introducing new inventions specialized for commercialization, MARII conducted programmes and workshops on technology adaptation, SIRIM offered infrastructure to measure industrial equipment, MARA launched Rural Premises Transformation Programme to assist entrepreneurs upgrading their premises and infrastructure while PUNB introduced PROSPER Property Programme, focusing on securing strategic premise for businesses (NEP 2030, 2019).

Governance

The rapid dissemination of massive technologies demands additional safeguards due to risks and threats. The threats must be handled by the government through legislations. Failing of government in alleviating such threats would prompt to prolonged social problems such as unemployment and wider gap of disparity in the country. "Industry4WRD: National Policy on Industry 4.0" a blueprint outlined by the Ministry of Trade and Industry announced in 2018 was structured to advocate manufacturing sector and its related services on embracing digital technologies and practices through adoption of associated technologies linked to their businesses.

Another regulation by the Malaysian government is The Communications and Multimedia Act 1998 which came into effect on 1 April 1999, seek as a legislative mechanism for the integration of telecommunications, broadcasting and computer industries aiming in making the country as a worldwide communications and multimedia knowledge services centre, while maintaining the privacy and protection of data for SMEs through the National Cyber Security Strategy (Asian Productivity Organization, 2019).

\section{Contribution of the Study}

Agostini \& Nosella (2019) in their study highlighted that governments are promoting businessto-external collaborations between SMEs and external players include intermediaries, universities and innovative firms by assisting SMEs in digitalizing their businesses both financially and structurally and by conducting training programs. They observed that via these governments-promoted initiatives, SMEs have started spending in advanced technologies, 
and have built a variety of ties with external stakeholders, not just suppliers and clients, but also with technology vendors and innovative firms.

SMEs should reflect on their weakness and act on the mechanisms listed so they can develop transformative market strategies and build partnership that beneficial them in a long term. Besides, the mechanisms can work as a subject of benchmark for readiness of new technologies, especially for developing countries with the same occurrence as Malaysia. While for the government side, the application for any stimulus packages, grants or loan schemes should be hassle-free to apply otherwise the fallout will be much of consequence to SMEs. However, this study is conceptual in nature with potential mechanisms to tackle issues of the readiness of new technology. Further study with empirical data on SMEs readiness towards Industry 4.0 in Malaysia can be conducted by future researchers.

\section{Conclusion}

In summary, Malaysian government and related bodies ardently executed various mechanisms and revised regulations to address readiness issue circulating among SMEs towards the embedded of Industry 4.0. The concerted efforts include providing fund and incentive, ecosystem support, training, coordinate standards and digital integration, built infrastructure and regulating the authority. The government has made a significant breakthrough in endorsing the welfare of SMEs. It is time to maintain sustained endeavours from traditional to digital economy and hoping for them to grow exponentially in line with the country's enterprise growth.

Such endeavours should be carried out by policymakers and SMEs themselves. Accountable bodies need to regulate policy on new business models especially on e-commerce. SMEs on the other hand, must unfold their best potential and be flexible to take the transition pace as a challenge. There are still many human and manual procedures involved in their everyday operations, which are neither really profitable nor encourage productivity. Other than that, addressing issues of cybersecurity threats emerging from technological change must be on the top priority as well. The transformation is not revolving on the implementation phase only but also transform business practices and everyday operations.

\section{Recommendations}

It is imperative for small companies to invest in the modern concept of digital economy as a mean of enhancing productivity. Business operation must not be limited to Internet usage for marketing and communications purpose or record keeping on office productivity using Microsoft Excel only. The operation must be less human intervene and more machines involved. However, the issue lies when SMEs could not afford such technologies with limited financial and resources in hands. SMEs may be able to thrive and solve the internal and external limitations of a market growth with ample working capital and by that means, more financial incentives should be offered by the government (Ombi, Ambad \& Bujang, 2018).

Training support on using digital tools include cloud computing software, artificial intelligence, machine learning and data analytics must be carried out extensively on a widescale so it can reach SMEs in rural area. Digital mentality must be instilled in every owner of SMEs so they can perceive their business through the lens of technology advancement to unlock the next level of achievement. Abundant of documentation drafting and strategies coordination are called for. The most exemplary policy can be formulated from partnership that is built nationally between the government and stakeholders. Policymakers need to critically nurture their own sense on anticipating the future while acknowledging prospects 
and challenges and how lateral solutions can be applied for the basic functioning of the country. However, any efforts or social reconstruction will not be effective as long as the roles from SMEs remain untapped or at the edge. The structure and management of the SME itself must be supportive and not attach on the culture of dependency.

\section{References}

Agostini, L., \& Nosella, A. (2019). The adoption of Industry 4.0 technologies in SMEs: results of an international study. Management Decision, 58(4), 625-643. https://doi.org/10.1108/MD-09-2018-0973

Agostini, L., \& Filippini, R. (2019). Organizational and managerial challenges in the path toward Industry 4.0. European Journal of Innovation Management, 22(3), 406-421. https://doi.org/10.1108/EJIM-02-2018-0030

Asian Productivity Organization. (2019). Gearing Up to Industry 4.0 Digitization Strategies for SMEs. Retrieved from https://www.apo-tokyo.org/publications/wpcontent/uploads/sites/5/Gearing-Up-To-Industry-4.0-Digitization-Strategies-forSMEs.pdf

Chin, Y. W., \& Lim, E. S. (2018). SME Policies and Performance in Malaysia. Yusof Ishak Institute, Economics Working Paper, 3. 1-40. Unpublished.

Dallasega, P., Rauch, E., Linder, C. (2018). Industry 4.0 as an enabler of proximity for construction supply chains: a systematic literature review. Comput. Ind. 99, 205-225. https://doi.org/10.1016/j.compind.2018.03.039

Department of Statistics Malaysia. (2019). Contribution of Digital Economy was 18.5 per cent to National Economy. Retrieved from

https://www.dosm.gov.my/v1/index.php/index.php?r=column/ctheme\&menu_id=b0pIV1E 3RW40VWRTUkZocEhyZ1pLUT09\&bul_id=UERrcjExbnRKd3NwQ0Y3V011RngyQT09

Drath, R., \& Horch, A. (2014). Industrie 4.0: Hit or hype? [industry forum], IEEE Industrial Electron Magazine, 8(2), 56-58. https://doi.org/10.1109/MIE.2014.2312079

Imran, M., Hameed, W. U., \& Haque, A. U. (2018). Influence of Industry 4.0 on the Production and Service Sectors in Pakistan: Evidence from Textile and Logistics Industries. Social Sciences, 7(246), 1-21. https://doi.org/10.3390/socsci7120246

Ismail, M. R., \& Zakaria, Z. (2018). The effects of entrepreneurship orientation, government support and internalization on Malaysian SMEs performance. International Journal of Academic Research in Business and Social Sciences, 8(7), 453-468. https://doi.org/IJARBSS/v8-i7/4387

Ling, Y. M., Hamid, N. A. A., \& Chuan, L. T. (2020). Is Malaysia ready for Industry 4.0? Issues and Challenges in Manufacturing Industry. The International Journal of Integrated Engineering, 12(7), 134-150. https://doi.org/10.30880/ijie.2020.12.07.016

Malaysian Investment Development Authority. (2018). Pushing Technology for SMEs. Retrieved from https://www.mida.gov.my/home/7538/news/pushing-technology-forsmes/

Ministry of Trade and Industry. (2018). Industry4wrd: National Policy on Industry 4.0. Retrieved from https://www.miti.gov.my/miti/resources/National\%20Policy\%20on\%20Industry\%204. 0/Industry4WRD_Final.pdf

Molino, M., Cortese, C. G., \& Ghislieri, C. (2020). The Promotion of Technology Acceptance and Work Engagement in Industry 4.0: From Personal Resources to Information and 
Training. International Journal of Environmental Research and Public Health, 17 (2438), 1-15. https://doi.org/doi:10.3390/ijerph17072438

Muhamad, M. Q. B., Mohamad, S. J. A. N. S., \& Nor, N. M. (2020). Prefiguring Issues of SMEs Readiness in Malaysia as the Future of Industry 4.0 Unfolds. International Journal of Academic Research in Business and Social Sciences, 10(12), 1283-1292. https://doi.org/6007/IJARBSS/v10-i12/7635

Musa, H., \& Chinniah, M. (2016). Malaysian SMEs development: future and challenges on going green. Procedia - Social and Behavioral Science, 224, 254-262. https://doi.org/10.1016/j.sbspro.2016.05.457

National Entrepreneurship Policy 2030, (2019). Retrieved from https://www.medac.gov.my/admin/files/med/image/portal/NEP2030-Final.pdf

Ombi, N., Ambad, S. N. A., \& Bujang, I. (2018). The Effect of Business Development Services on Small Medium Enterprises (SMEs) Performance. International Journal of Academic Research in Business and Social Sciences, 8(3), 114-127. https://doi.org/doi:10.3390/10.6007/IJARBSS/v8-i3/3910

Singh, D. S. M., \& Hanafi, N. B. (2020). Innovation Capacity and Performance of Malaysian SMES. International Journal of Academic Research in Business and Social Sciences, 10(2), 665-679. https://doi.org/6007/IJARBSS/v10-i2/6956

SME Corporation Malaysia. (2018). Propelling SMEs in the Digital World. Retrieved from https://www.smecorp.gov.my/index.php/en/resources/2015-12-21-10-5522/news/3475-propelling-smes-in-the-digital-world

SME Corporation Malaysia. (2018). SME Annual Report 2017/2018 - Access to Finance. Retrieved from https://www.smecorp.gov.my/images/SMEAR/SMEAR2017/ENG/Chapter6.pdf

Zhu, K., Kraemer, K. L., \& Xu, S. (2006). The process of innovation assimilation by firms in different countries: a technology diffusion perspective on e-business. Management science, 52(10), 1557- 1576 